\title{
Debate on Genetic Resources Accessed Ex Situ in the context of the Nagoya Protocol
}

\section{Hasrat Arjjumend}

Centre for International Sustainable Development Law, McGill University Faculty of Law, Montreal (Quebec) H3A 1X1, Canada. E-mail: harjjumend@gmail.com

How to cite this paper: Arjjumend, $\mathrm{H}$. (2018). Debate on Genetic Resources Accessed Ex Situ in the Nagoya Protocol. Grassroots Journal of Natural Resources, 1(1): 5-12. Doi:

https://doi.org/10.33002/nr2581.6853.01011

Received: 09 June 2018

Reviewed: 29 June 2018

Provisionally Accepted: 30 June 2018

Revised: 29 July 2018

Finally Accepted: 01 August 2018

Published: August 13, 2018

Copyright $(2018$ by author(s) and

The Grassroots Institute.

This work is licensed under the Creative Commons Attribution International License (CC BY 4.0).

http://creativecommons.org/licenses/by/4.0/

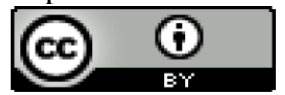

Open Access

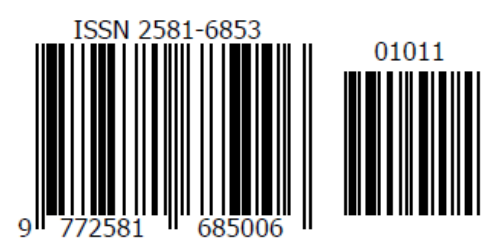

\section{Abstract}

Recently enacted two international laws - Nagoya Protocol on access and benefit sharing (ABS) and International Treaty on Plant Genetic Resources for Food and Agriculture (ITPGRFA) - deal with the access/utilization of and benefit sharing arising out from genetic resources and associated traditional knowledge (TK). Both the instruments lack relevant appropriate provisions guiding the countries to take administrative or legislative measures for covering and addressing the benefit sharing from the ex situ collections of genetic resources that were accessed well before the Nagoya Protocol came into existence. Developed nations show no willingness to share the benefits arising from the biological resources which they accessed from developing countries and retain ex situ. As a result, most affected entity would be the indigenous people and local communities (ILCs) - the custodians of most of the local biological resources - who would receive no benefits. The implications on this crucial issue will be critically reviewed in this article to identify appropriate solutions to this bottleneck using a few case studies.

\section{Keywords}

Ex Situ Collection; Nagoya Protocol; Genetic Resources; Benefit Sharing 


\section{Introduction}

For millennia, the international organizations and United Nations have conserved the genetic resources of huge array of wild and domesticated plants and animals. With the intention of preserving the genetic stock of biodiversity from all over the world, the herbaria, museums, botanical gardens, gene banks, etc. have accessed specimen collections for over a century. Globally, there are total of 2,107 aquaria and zoos in 125 countries. Additionally, many private collectors or other not-for-profit groups hold animal genetic resources. Similarly, there are approximately 2,000 botanical gardens in 148 counties cultivating or storing an estimated 80,000 taxa of plants (Edward, Havens and Maunder, 2004, p.91, 10-11). For instance, the International Bureau of Plant Genetic Resources (IBPGR; since 2006 Biodiversity International) sponsored more than 500 collecting expeditions from national and international institutions to most countries of the world, during which over 225,000 plant samples were gathered (Thormann et al., 2012). This wealth of landraces and wild relatives was distributed to 49 selected gene banks to conserve the germplasm for the long-term and to over 500 gene banks for conservation and use (Maggioni et al., 2015). According to the Second Report on the State of the World's Plant Genetic Resources for Food and Agriculture (FAO, 2010), there were more than 1750 reported individual gene banks or germplasm collections worldwide in 2015, conserving an estimated number of about 7.4 million accessions (FAO, 2010). In Europe, approximately 1.9 million accessions are maintained in more than 500 gene bank or collections (WIEWS, 2013).

After the commercial access and utilization to such genetic resources began, the questions were raised globally demanding the imposition of access and benefit sharing (ABS) norms on these ex situ collections that occurred well before Convention on Biological Diversity (CBD) or Nagoya Protocol came into existence. It is believed that the Nagoya Protocol is a legally binding international instrument, which endeavours to advance national access and benefit-sharing (ABS) legislation and/or administrative measures and regulated access to genetic resources and benefitsharing arising out of the commercial utilisation thereof (Teran, 2016: cited in Arjjumend et al., 2017, pp.56-57). Teran (2016) further reiterated that these debates are particularly important because the parties need to undertake domestic measures in compliance with the Nagoya Protocol, due to increased awareness about the protocol and its requirements among a variety of stakeholders (Arjjumend et al., 2017, p.57). However, the Nagoya Protocol does not apply to genetic resources over which the Parties may not exercise their sovereign rights, such as areas beyond national jurisdiction. According to Buck and Hamilton (2011), Articles 5(1) and 6(1) of Nagoya Protocol refer to the "country of origin" as the country that possesses the genetic resources in situ - that is, where the genetic resources exist within ecosystems and natural habitats, and, in the case of domesticated or cultivated species, in the surroundings where they have developed their distinctive properties. Thus, it is clear from the Protocol that the obligations of benefit-sharing do not apply to ex situ collections of user Parties, despite the fact that the genetic resources were acquired from certain provider Parties before CBD came into existence. Therefore, the temporal scope of Nagoya Protocol is restricted to the date of its promulgation in 2010. Applied on the genetic resources of agricultural crops, the International Treaty on Plant Genetic Resources for Food and Agriculture, 2001 (ITPGRFA) also has ambiguity on the issue of benefit sharing if genetic resources of Annex- $\mathrm{I}^{1}$ priority crops (64 crops) are kept in ex situ collections or utilized for commercial gains.

${ }^{1}$ http://www.fao.org/fileadmin/templates/agphome/documents/PGR/PubPGR/ResourceBook/annex1.pdf

Hasrat Arjjumend 
Based on the extensive literature review, this discussion paper explores the pertinent questions around the issues of benefit sharing if biological resources of a provider country were accessed $e x$ situ and utilized for commercial or non-commercial purposes. The paper would draw attention in the end to need of addressing the benefit sharing arising from the ex situ collections by evolving legible benefit sharing mechanisms.

\section{Temporal Scope of Nagoya Protocol}

The Nagoya Protocol unfortunately does not deal with the genetic resources accessed/ acquired by Parties or entities before the Protocol. For example, if Switzerland has already kept certain genetic resource accessed from Nepal without any prior informed consent (PIC) or mutually agreed terms (MAT) signed or even without any knowledge of Nepal government or ILCs, the Nagoya Protocol has no provision to deal with such a situation, let alone guiding any sharing of the benefits from the utilization of those particular genetic resources. Arjjumend (2016) conducted a study by gathering expert opinions of academic/research institutions, CSOs and concerned individuals. He concluded that the Nagoya Protocol appeared to be a weak international legal instrument for guiding the mandatory sharing of benefits being obtained from utilization of genetic resources held ex situ by user Parties. In his findings he highlights that developing countries can seek such benefit sharing by virtue of provider Parties that would take legislative, administrative or policy measure seeking benefit sharing from utilization of genetic resources held ex situ by user Parties. But, the Nagoya Protocol does not provide such empowerment to the developing nations. Arjjumend (2016) among others has pointed out that the legislation of State does, as a rule, not have an extraterritorial effect. State legislation would not be helpful, as there is no unilateral general way to subject all ex situ resources that have been acquired before the entry into force of the CBD or the Nagoya Protocol, respectively, under the ABS regime (Arjjumend, 2016). If the resources are accessed after the entry into force (of the CBD - still debated) of the Nagoya Protocol, there is no problem anyway.

Lassen (2016) elaborates further that the question of temporal scope was one of the most contentious issues in the negotiations leading to the adoption of the Nagoya Protocol. Most developing countries supported utilization as the trigger for benefit sharing obligations, whereas developed countries opposed it. As no compromise language was reached during the negotiations, the Nagoya Protocol remains silent on the issue of temporal scope, leaving it up to member States to clarify this ambiguity through their implementing legislation (Lassen, 2016). As our analysis of surveyed opinions indicates, the developing countries particularly do not act in their legislations on this contentious issue of accessed ex situ genetic resources or TK in the absence of adequate empowerment by Nagoya Protocol itself. On the contrary, the developed nations have been taking advantage of weak position of Nagoya Protocol on this particular front. For example, EU prefers Option T-1 $1^{2}$ over the Option T- $2^{3}$ in this connection. Position of EU is reflected in the following statements:

"Option T-1 creates a high level of legal certainty and clarity for EU users. This is particularly important for industries where research and development processes typically span many years (e.g. pharmaceutical industry, plant breeding). Option T-1 is clearly

\footnotetext{
${ }^{2}$ Option T-1: Applying implementing measures to genetic resources or associated traditional knowledge acquired after entry into force of the Nagoya Protocol for the EU.

${ }^{3}$ Option T-2: Applying implementing measures to genetic resources or associated traditional knowledge acquired since entry into force of the CBD and utilised after entry into force of the Nagoya Protocol for the EU.
} 
preferable. It combines legal certainty for EU users with a higher likelihood to meet important social and environmental objectives. Conversely, Option T-2 would raise many economic and legal, in part constitutional, concerns, and, also would be unlikely to contribute to fulfilling the set social and environmental objectives. The main drawback of Option T-2 is its effect on legal certainty of EU users. The creation of new obligations under EU law for "new or continuous" utilisation activities would raise many legal and practical questions." (European Commission, 2012, p.43)

In contrast to these new and broad provisions, the temporal scope, as defined in Article 5(1) of Nagoya Protocol, primarily reflects the position of developed countries arguing for a scope of the Nagoya Protocol to be as narrow as possible. The obligation to share benefits arising from the utilization of genetic resources only seems to apply when the resources were accessed in a Party to the Protocol, meaning after the entry into force of the Protocol. The developed countries dispute that benefits arising from the continued use of resources that have been accessed before the entry into force of the Protocol are covered by the international rules (Frein and Meyer, 2011). However, in connection with Article 4(4), which says that the Nagoya Protocol is the instrument for the implementation of the ABS provisions of the Convention, this position seems not to be too strong. When analyzed comparatively the Article 2, Article 3 and Article 5(1) of Nagoya Protocol, we are led to the interpretation that the trigger for benefit sharing is 'utilization' rather than 'access'. Hence, new interpretation would lead to the current application of the Protocol, regardless of when physical access took place (i.e., whether it took place before or after the Nagoya Protocol came into force) (Lassen, 2016).

\section{Field Implications of Ex Situ Collections and ABS Regimes}

Some individual countries and few regional councils have shown the ways how the issues of $e x$ situ collections may be resolved. Here some examples are illustrated. While establishing the Common Regime on Access to Genetic Resources, the Decision 391 of Commission of the Andean Community ${ }^{4}$ embraces all types of uses of genetic resources, including genetic resources held in ex situ and in situ conditions as well as their derivative products and intangible components. The Decision 391 defines ex situ conditions by exclusion, as those that are not in situ. Similarly, the MIRRI-mBRC is advised to only distribute (or continue distributing) genetic materials of ex situ collections of microbes to third parties under an material transfer agreement (MTA) that obliges recipients who want to utilize the genetic resource for research and development with commercial intent, to contact at least the appropriate authority in the country of origin of the resource, in advance of such utilization, to negotiate in good faith on the terms of any benefit sharing (Verkley, Martin and Smith, 2016, p.12). However, in the absence of appropriate domestic ABS legislation/provisions, the user entities face difficulties in signing MTA before utilization of the genetic material.

In order to look into the site specific implications of the inclusion of temporal scope in domestic legislations, Arjjumend (2016) conducted an unpublished study in 12 Asian countries. Posed to concerned academic institutions and civil society organizations (CSOs), prominent question was: "Should the developing countries include provisions in their ABS law or administrative/policy

\footnotetext{
${ }^{4}$ Decision No. 391 was issued in Caracas, Venezuela by the Commission of the Cartagena Agreement (also known as 'the Commission of the Andean Community') on July 2, 1996 and published in the Official Gazette of the Cartagena Agreement No. 213 of July 17, 1996, in Lima, Peru. Online: http://www.wipo.int/wipolex/en/details.jsp?id=9446
} 
measure to seek benefit sharing from utilization of genetic resources held ex situ by user countries, and which they are the country of origin of?" In response to the question, nearly onethird (30\%) of academic/research institutions responded affirmatively that the developing countries could seek such benefit sharing (as the Nagoya Protocol empowers the provider Parties to take legislation, administrative or policy measure seeking benefit sharing from utilization of genetic resources held ex situ by user Parties). On the other hand, majority (60\%) of the academic/research institutions had views that the developing countries could seek such benefit sharing (but the Nagoya Protocol does not empower the provider Parties to take legislation, administrative or policy measure seeking benefit sharing from utilization of genetic resources held ex situ by user Parties) (Arjjumend, 2016). On the same question, 37.5\% of surveyed CSOs replied affirmatively that the developing countries could seek such benefit sharing (as the Nagoya Protocol empowers the provider Parties to take legislation, administrative or policy measure seeking benefit sharing from utilization of genetic resources held ex situ by user Parties) (Arjjumend, 2016). On the other side, same proportion (37.5\%) of CSOs had expressed views that the developing countries could seek such benefit sharing (but the Nagoya Protocol does not empower the provider Parties to take legislation, administrative or policy measure seeking benefit sharing from utilization of genetic resources held ex situ by user Parties). Additionally, 25\% of CSOs expressed that the developing countries cannot seek such benefit sharing (because the Nagoya Protocol does not empower the provider Parties to take legislation, administrative or policy measure seeking benefit sharing from utilization of genetic resources held ex situ by user Parties) (Arjjumend, 2016).

Let us see what is happening in EU countries in the context of benefit sharing from the ex situ collections. In practice, the European Union facilitated 28-member countries to comply with the codes of ABS in order to retain the ex situ genetic resources. Currently, the following nonbinding ABS codes (Broggiato et al., 2015, p.12) are in practice in EU nations: (1) the MicroOrganisms Sustainable Use and Access Regulation International Code of Conduct (MOSAICC) developed within the framework of culture collections in 1999 and revised in 2009. It is currently under revision in light of the Nagoya Protocol and translated into the Transparent User Friendly System of Transfer for Science and Technology (TRUST); (2) the International Plant Exchange Network (IPEN) Code of Conduct for botanic garden governing the acquisition, maintenance and supply of living plant material, developed in 2001; (3) the Consortium of European Taxonomic Facilities (CETAF) Code of Conduct and Best Practice for Access and Benefit-sharing, developed in 2012. Yet, according to Lassen (2016, p.8), the EU regulation on $\mathrm{ABS}^{5}$ takes the position that physical access to a genetic resource or associated traditional knowledge in the country of origin is reference affair for ABS obligations, and it limits the obligations of users of genetic resources and associated TK to uses of resources that have been physically accessed in provider countries after the Nagoya Protocol has been ratified by both the EU and the country of origin (Article 2.1 of EU Regulation ${ }^{6}$ ). Emphasis of EU regulation is on the fact that EU regulation applies only in case when the member user country accesses the genetic resource or TK from a provider country having ratified the Nagoya Protocol. EU regulation does not apply to

\footnotetext{
${ }^{5}$ EU ABS Regulation: Regulation (EU) No. 511/2014 of the European Parliament and of the Council on Compliance Measures for users from the Nagoya Protocol on Access to Genetic Resources and the Fair and Equitable Sharing of Benefits arising from their Utilization in the Union was adopted on 16 April 2014.

${ }^{6}$ Article 2.1 reads: "This Regulation applies to genetic resources over which States exercise sovereign rights and to traditional knowledge associated with genetic resources that are accessed after the entry into force of the Nagoya Protocol for the Union" and access is defined as "the acquisition of genetic resources or of traditional knowledge associated with genetic resources in a Party to the Nagoya Protocol".
} 
(and keep beyond its scope) any access if done in provider country having not ratified Nagoya Protocol. Particularly, EU regulation is silent on asking EU users to seek Prior Informed Consent (PIC) and negotiate Mutually Agreed Terms (MAT) in cases that are beyond the scope of the EU regulation, but where the national provider legislation would demand PIC and MAT. Swiss Nagoya Ordinance ${ }^{7}$ of 11 December 2015 has also followed the same logic as the EU Regulation regarding temporal scope (Lassen, 2016, p.8).

While comparing above findings of the study of Arjjumend (2016) with sporadic examples of provider countries, the situation of developing nations still seems grim. For example, Brazil's new ABS law ${ }^{8}$ asks users who accessed, utilized or transferred genetic resources or associated TK out of the country illegally after 2000 (considering previous existing law ${ }^{9}$ from year 2000) to regularize their situation under the new law within a year ${ }^{10}$. The Brazilian law may be witnessed simply regularizing the pre-2000 access of genetic resources from Brazil, but not acting on ex situ access and utilization by users during pre-CBD era. On the other hand, Kenya has acted strongly on this issue. The Kenyan Wildlife Conservation and Management (Bio-prospecting) Regulations, $2016^{11}$ make direct reference to genetic resources held outside of the country (i.e. including those that were physically accessed ${ }^{12}$ before the entry into force of the Nagoya Protocol). Like Kenya, hardly any provider country has such strict provisions in domestic ABS legislation.

\section{Conclusion}

There is a huge repository of biological resources held by various developed countries and international institutions where the plant materials and/or animal resources had been accessed long ago from CBD or Nagoya Protocol came into force and are still kept for educational, research, conservation and other purposes. Obviously, at the time of accessing those materials the ABS systems were absent. However, as the ABS regime has evolved, and the ex situ collections have been questioned in the benefit sharing contexts it is inevitable to find ways how the complexities of accessing and benefit sharing be simplified. As a matter of fact, the lobby of developed nations has no willingness to comply with such obligations. Nagoya Protocol has no clear provisions explaining the mechanism of addressing benefit sharing concerns in relation to ex situ collections in museums, herbaria, gardens, etc. As a result, the indigenous people and local communities (ILCs) as the providers of genetic resources and TK will likely lose the battle. It is because the trend of innovations utilizing the biological diversity, especially ex situ

\footnotetext{
${ }^{7}$ www.admin.ch/opc/en/classified-compilation/20150120/index.html

${ }^{8}$ Brazilian Law No. 13.123 of May 20, 2015 (Access and Benefits Sharing of Genetic Resources and Associated Traditional Knowledge)

${ }^{9}$ Medida Provisoria No. 2.186-16 of 23 August 2001: www.planalto.gov.br/ccivil_03/mpv/2186-16.htm

${ }^{10}$ Art. 38. Deverá regularizar-se nos termos desta Lei, no prazo de 1 (um)ano, contado da data da disponibilização do Cadastro pelo CGen, ousuário que, entre 30 de junho de 2000 e a data de entrada em vigor destaLei, realizou as seguintes atividades em desacordo com a legislaçãoem vigor à época:I - acesso a patrimônio genético ou a conhecimento tradicional associado; II - acesso e exploração econômica de produto ou processo oriundo doacesso a patrimônio genético ou a conhecimento tradicionalassociado, de que trata a Medida Provisória no 2.186-16, de 23 deagosto de 2001;III - remessa ao exterior de amostra de patrimônio genético; ouIV - divulgação, transmissão ou retransmissão de dados ou informaçõesque integram ou constituem conhecimento tradicional associado.

${ }^{11}$ www.kws.go.ke/download/file/fid/2217

${ }^{12}$ Art.3.2:" These Regulations shall apply to bio-prospecting activities of any wild biological resources found in Kenya including wild species of flora and fauna and microorganisms, both (in-situ and ex-situ) and other wild biological resources sourced from Kenya and held in foreign ex-situ collections."
} 
collections, is worrying (Oldham et al., 2013). As a result, it would reduce the flow of direct benefits to ILCs because much of the germplasm and genetic resources have been accessed/collected in the past, leaving less demand for new access. This will reportedly complicate the benefit sharing process with original providers, and gene banks could be the main recipients of benefits (see also, Robinson, 2015, p.204). Therefore, at least for ethical reasons the holders of biological resources accessed ex situ long before the CBD or Nagoya Protocol came into existence must come forward to devise ways of sharing the benefits to respective Parties, entities or communities from the dates decided appropriately.

\section{References}

Arjjumend, H. (2016). International governance of biodiversity: A study of ABS regime. PhD thesis. MMAJ Academy of International Studies, Jamia Millia Islamia Central University: New Delhi. Online: https://www.researchgate.net/publication/325663561_International_Governance_of_Biodiv ersity_A_Study_of_ABS_Regime

Arjjumend, H., Koutouki, K., Alam, S. and Koivurova, T. (2017). The Space for Indigenous People and Local Communities: Participation in Policy Making and Benefit Sharing Negotiations. World Affairs: Journal of International Issues, 21(4): 56-72.

Broggiato, A., Dedeurwaerdere, T., Batur, F. and Coolsaet, B. (2015). Introduction. Access Benefit-Sharing and the Nagoya Protocol: The Confluence of Abiding Legal Doctrines. In Brendan Coolsaet, Fulya Batur, Arianna Broggiato, John Pitseys and Tom Dedeurwaerdere, eds., Implementing the Nagoya Protocol: Comparing Access and Benefit-Sharing Regimes in Europe, Leiden/Boston: Brill Nijhoff.

Buck, M. and Hamilton, C. (2011). The Nagoya Protocol on Access to Genetic Resources and the Fair and Equitable Sharing of Benefits Arising from their Utilization to the Convention on Biological Diversity. RECIEL, 20(1), p.47.

Edward, G., Havens, K. and Maunder, M. (2004). Ex situ plant conservation: supporting species survival in the wild. Covelo, CA, USA: Island Press.

European Commission (2012). Commission Staff Working Document: Impact Assessment. Accompanying the document Proposal for a Regulation of the European Parliament and of the Council on Access to Genetic Resources and the Fair and Equitable Sharing of Benefits Arising from their Utilization in the Union. Part 1. European Commission: Brussels, 4.10.2012, SWD (2012) 292 final.

FAO (2010). The Second Report on the State of the World's Plant Genetic Resources for Food and Agriculture. Rome: Food and Agriculture Organization of the United Nations (FAO).

Frein, M. and Meyer, H. (2011). Nagoya Protocol on Access and Benefit Sharing (ABS) under the Convention on Biological Diversity (CBD). Background-Paper.D, Bonn: EED \& WWF-Germany.

Lassen, B. (2016). The two worlds of Nagoya - ABS legislation in the EU and provider countries: discrepancies and how to deal with them. Cape Town: Public Eye, Zurich and Natural Justice.

Maggioni, L., Noriega, I.L., Lapena, I., Holubec, V. and Engels, J.M.M. (2015). Collecting Plant Genetic Resources in Europe: A Survey of Legal Requirements and Practical Experiences. In Brendan Coolsaet, Fulya Batur, Arianna Broggiato, John Pitseys and Tom Dedeurwaerdere, eds., Implementing the Nagoya Protocol: Comparing Access and BenefitSharing Regimes in Europe, Leiden/Boston: Brill Nijhoff.

Oldham, P., Hall, S. and Forero, O. (2013). Biological diversity in the patent system. PLOS One, 
8(11):1-10.

Robinson, D. F. (2015). Biodiversity, Access and Benefit-Sharing: Global Case Studies. London: Earthscan/Routledge.

Teran, M.Y. (2016). The Nagoya Protocol and Indigenous Peoples. The International Indigenous Policy Journal, vol.7, no.2, pp.1-25.

Thormann, I., Gaisberger, H., Mattei, F., Snook, L. and Arnaud, E. (2012). Digitization and Online Availability of Original Collecting Mission Data to Improve Data Quality and Enhance the Conservation and Use of Plant Genetic Resources. Genetic Resources and Crop Evolution, 59(5): 635-644.

Verkley, G., Martin, D. and Smith, D. (2016). Best Practice Manual on Access and Benefit Sharing: May 2016 - Version 1.0. Portugal: Microbial Resource Research Infrastructure.

WIEWS (2013). World Information and Early Warning System on Plant Genetic Resources for Food and Agriculture. Accessed December 20, 2013, http://apps3.fao.org/wiews/wiews.jsp. 